\title{
Kepuasan, Kepercayaan, dan Brand Switching Konsumen Produk Kosmetik Berlabel Halal
}

\author{
Tamamah', Abdul Muhid ${ }^{1}$ \\ ${ }^{1}$ Fakultas Psikologi dan Kesehatan UIN Sunan Ampel Surabaya \\ DOI: http://doi.org/10.29080/jpp.v\%vi\%i.225
}

\begin{abstract}
Brand switching is a behavior of changing brand which is commonly used to other brands for certain reasons. This study aims to examine a correlation between customer satisfaction and trust with brand switching behavior in using cosmetic products labeled as halal. The research subjects were female employees who worked at the UIN Sunan Ampel campus in Surabaya. The data were analyzed using multiple regression. The results showed that there was a correlation between consumer satisfaction with Brand Switching of cosmetic products labeled as halal. Meanwhile, it no correlation between consumer confidence in brand switching of cosmetic products labeled as halal.
\end{abstract}

Keywords : Brand switching, Customer satisfaction, Customer trust

\begin{abstract}
Abstrak : Brand switching merupakan perilaku melakukan perpindahan merek dari yang biasa digunakan ke merek lain karena alasan tertentu. Penelitian ini bertujuan menguji hubungan antara kepuasan dan kepercayaan konsumen terhadap perilaku brand switching produk kosmetik berlabel halal. Subyek penelitian adalah pegawai perempuan yang bekerja di kampus UIN Sunan Ampel Surabaya. Analisis daya yang digunakan adalah regresi linier berganda. Hasil penelitian menunjukkan bahwa terdapat hubungan antara kepuasan konsumen dengan Brand Switching produk kosmetik berlabel halal, dan tidak terdapat hubungan antara kepercayaan konsumen terhadap brand switching produk kosmetik berlabel halal.
\end{abstract}

Kata kunci : Brand switching, Kepuasan konsumen, Kepercayaan konsumen, Kosmetik berlabel halal

\section{Pendahuluan}

Kosmetik dengan sertifikat halal mengalami perkembangan yang sangat pesat di Indonesia (A. S. Hidayat \& Siradj, 2015). Hal itu menunjukkan semakin meningkatnya kesadaran masyarakat tentang pentingnya menggunakan produk yang terjamin kehalalannya dan kualitasnya (Mutaalimah, 2018). Di Indonesia ketentuan kosmetik berlabel halal sudah di atur dalam Undang-undang (UU) No 33 tahun 2104 tentang 
Jaminan Produk Halal (JPH) (E. Hidayat, 2018). Data LPPOM MUI mencatat bahwa pada 2016 terdapat 48 perusahaan dengan total 5.254 produk kosmetik halal dan pada 2017 sebanyak 64 perusahaan dengan total 3.219 (Bahtiyar, 2013; Tripeni, 2018). Hal ini menunjukkan kesadaran dari perusahaan kosmetik khususnya di Indonesia tentang pentingnya label halal.

Data tersebut juga menunjukkan persaingan yang ketat dalam industri kosmetik yang memiliki label halal antara merek lama dan baru (Bahtiyar, 2013). Selain itu perusahaan yang memproduksi barang harus mampu meningkatkan kepuasan dan kepercayaan konsumen agar tidak berpindah pada merek yang lain(Yoestini, 2012). Penelitian yang dilakukan Yosua dan Nurul (2016) menunjukkan bahwa variety seeking, promosi dan citra merek memiliki pengaruh terhadap keputusan perpindahan merek. Selain itu kebutuhan variasi, status sosial, kualitas, dan iklan berpengaruh terhadap keputusan konsumen untuk berpindah merek (Chatrin, 2006)(Faustine, 2015). Gunawan (2010) menambahkan bahwa persepsi merek dan kepercayaan konsumen atas produk berpengaruh terhadap peralihan merek (Gunawan, 2010).

Perpindahan merek (brand switching) merupakan pola pergantian atau perubahan penggunaan dari satu merek ke merek yang lain (Chatrin, 2006)(Petter dan Olson, 2002) . Konsep yang paling mendasari perilaku tersebut adalah kebutuhan manusia yang selalu berubah-ubah mengikuti perkembangan zaman. Brand switching diartikan oleh Ganes, Arnold, Reynold dalam Chatrin dan Karlina (2006) sebagai perilaku konsumen yang menggambarkan pergantian pemakaian dari satu produk atau merek yang sudah biasa digunakan ke produk atau merek yang lain (Assael, 1984)(Afzal, 2013). Dharmmesta menjelaskan bahwa brand switching merupakan perilaku konsumen yang melakukan perpindahan merek dari yang biasa digunakan pada merek lain karena alasan tertentu atau karena kurangnya informasi mengenai produk atau merek tersebut sehingga konsumen rentan untuk melakukan brand switching. (Chatrin, 2006; Widyasari, 2008)

Ada sejumlah faktor yang dapat menyebabkan terjadinya perilaku brand switching yaitu terbatasnya persediaan merek di pasaran dan penawaran yang beragam dari merek lain (Kotler \& Keller, 2010), atribut produk dan promosi (Tjiptono, 1997), persediaan produk (Aaker, 1996), ketidakpuasan konsumen (Ribhan dalam Rasyada \& Seotrizola, 2015), variety seeking, harga(Lamb, Hair, \& McDaniel, 2001), iklan (Hsu dan Chang dalam Rasyada \& Seotrizola, 2015), kepuasan dan kepercayaan konsumen (Assael, 1984), munculnya produk baru, kualitas dan distribusi dan hilangnya kepercayan konsumen terhadap merek sebelumnya (Shi Cheung \& Prendergast dalam Tauriana \& Christine, 2011). Kualitas layanan, citra merek, kepuasan konsumen dan kepercayaan konsumen juga membentuk perilaku brand switching (Raza, 2015). Sementara itu Ganes, Arnold, Reynold menambahkan ada tiga hal yang menyebabkan terjadinya perilaku brand switching yaitu keinginan untuk berpindah ke merek lainnya, ketidaksediaan menggunakan kembali merek yang sama, dan keinginan untuk mempercepat penghentian penggunaan (Ganesh, Arnold, \& Reynolds, 2006).

Kepercayaan konsumen terhadap merek adalah salah satu dari sekian faktor yang mempengaruhi perilaku brand switching. Kepercayaan konsumen adalah sebuah pemikiran deskriptif yang dimiliki seseorang tentang sesuatu (Philip Kotler \& Amstrong, 2017). Kepercayaan terhadap merek adalah terpenuhinya harapan kinerja produk serta tercapainya kepuasan dilihat dari sudut pandang konsumen dan penilaian positif konsumen terhadap merek (Lau \& Lee, 1999; Cortabile, 2002). Upaya membentuk kepercayaan pada konsumen merupakan salah satu cara untuk menjadikan konsumen loyal pada suatu produk atau merek. Menurut Boon dan Holmes (Lau \& Lee, 1999) ketika individu telah memberikan kepercayaan pada pihak lain, maka akan dimungkinkan terbentuknya positive behavioral intetion terhadap pihak tersebut. Demikian pula saat konsumen sudah mempercayai suatu produk atau merek maka kemungkinan akan terbentuk positive buying intention yang semakin besar pada produk atau merek tersebut. 
Assael menjelaskan bahwa Intention (niat) merupakan salah satu komponen dari sikap di mana sikap itu terdiri dari kognitif, afektif, dan konatif. Struktur kognitif sama halnya dengan struktur keyakinan, yang berarti bahwa informasi yang diterima oleh konsumen mengenai suatu merek atau produk harus menunjukkan superioritas dari pada produk atau merek yang lain agar konsumen tidak melakukan perpindahan merek. Struktur afektif kaitannya dengan tingkat kesukaan para konsumen pada suatu merek harus lebih tinggi dari pada merek pesaing. Struktur konatif atau struktur niat konsumen mempunyai niat untuk membeli, jika tingkat kepercayaan konsumen terhadap produk atau merek yang digunakan tinggi, maka kemungkinan akan terjadi positive buying intention namun jika tingkat kepercayaan konsumen rendah terhadap produk atau merek maka akan terbentuk intention to Brand Switching (Assael, 1998).

Menurut Setiadi (2003) kepercayaan konsumen terhadap produk juga memiliki hubungan dengan adanya intensi perpindahan merek (brand switching), di mana kepercayaan konsumen berpengaruh pada sikap sedangkan sikap perpengaruh pada perilaku yang secara umum bergantung pada keterlibatan konsumen dalam menggunakan suatu produk atau merek. Jika konsumen memiliki keterlibatan yang tinggi pada pembelian suatu produk atau merek maka akan tinggi kepercayaan konsumen pada produk atau merek tersebut. Sebaliknya Jika konsumen memiliki keterlibatan yang rendah pada pembelian suatu produk atau merek maka akan rendah pula hubungannya pada kepercayaan konsumen para produk atau merek tersebut dan akan lebih tinggi hubungannya terhadap beralihnya konsumen para produk lain (brand switching). Hal ini juga di dukung oleh penelitian yang dilakukan oleh Gunawan (2010) yang menunjukkan bahwa persepsi merek dan kepercayaan konsumen terhadap merek berpengaruh terhadap perilaku brand switching konsumen. Penelitian yang dilakukan Ningsih (2012) juga menunjukkan bahwa brand awareness dan kepuasan konsumen berpengaruh terhadap brand switching.(Gunawan, 2010; Ningsih, 2012; Setiadi, 2003)

Selain faktor kepercayaan perilaku brand switching juga dipengaruhi oleh kepuasan konsumen terhadap suatu produk. Kepuasan adalah perasaan senang yang dirasakan oleh konsumen sebagai hasil perbandingan kinerja sebuah merek dengan ekspektasi yang dimiliki (P. Kotler, 2008). Wilkie (1994) menjelaskan bahwa kepuasan konsumen merupakan respon emosional mengenai pengalamannya dalam menggunakan produk tertentu. Kepuasan konsumen dapat diciptakan melalui kualitas pelayanan karena kepuasan merupakan kumpulan dari respon afektif (Assael, 1984; Giese \& Cote, 2002).

Kepuasan konsumen dapat menjadi penyebab terjadinya perilaku brand switching karena konsumen ingin mencoba produk baru yang belum pernah digunakan. Hal ini biasa terjadi pada konsumen yang memiliki keterlibatan emosional rendah serta kesadaran akan adanya perbedaan antara merek yang digunakan dengan merek lainnya (Assael, 1984). Jika konsumen memiliki keterlibatan yang rendah pada pembelian suatu produk atau merek maka akan rendah pula hubungannya pada kepercayaan konsumen pada produk atau merek tersebut sehingga hal ini dapat menyebabkan terjadinya perilaku brand switching (Setiadi, 2003).

Shukla (2004) menjelaskan bahwa kepuasan yang dirasakan oleh konsumen tidak menjamin sepenuhnya akan menyebabkan perpindahan merek karena konsumen juga menuntut peningkatan kualitas suatu produk. Produk yang selalu meningkatkan kualitanya akan dapat mengurangi kemungkinan terjadinya perilaku brand switching pada produk lain. Namun sebaliknya, bagi produk yang memiliki tingkat kualitas yang statis maka kemungkinan besar akan menyebabkan konsumen perpindah pada merek lain yang memiliki kualitas dinamis (Khairani, 2011; Shukla, 2004).

Selama ini yang menjadi fokus utama bagi banyak perusahan adalah membentuk kepuasan dan kepercayaan konsumen pada level yang tinggi agar tidak mudah menerima tawaran dari merek lain (Chan, 2010). Ekspektasi konsumen terhadap suatu produk dipengaruhi oleh pengalaman dari pembelian sebelumnya, masukan dari teman atau 
keluarga, serta janji dan informasi yang diberikan oleh produsen dan para pesaingnya. Namun, jika suatu produk dalam memberikan informasi atau janji yang dilebih-lebihkan (tidak sesuai dengan kenyataan) hal itu akan membangun harapan konsumen, Jika harapan tersebut tidak terpenuhi maka konsumen akan merasa tidak puas yang berakibat pada hilangnya kepercayaan konsumen pada produk tersebut (Hutami, 2018). Berdasarkan latar belakang ini, peneliti ingin mengetahui mengenai bagaimana hubungan kepuasan dan kepercayaan konsumen terhadap brand switching pada kosmetik berlabel halal pegawai wanita di lingkungan UIN Sunan Ampel Surabaya.

\section{Metode Penelitian}

Penelitian ini menggunakan metode kuantitatif korelasional. Subjek penelitian ini adalah pegawai wanita di UIN Sunan Ampel Surabaya yang diambil menggunakan teknik Simple Random Sampling (Muhid, 2019). Alat tiga alat ukur yang digunakan dalam penelitian ini yaitu skala perilaku brand switching, skala kepuasan konsumen, dan skala kepercayaan konsumen. Skala Brand Switching merupakan skala yang digunakan untuk mengukur tingkat perilaku Brand Switching dari satu produk kosmetik ke produk kosmetik yang lain. skala yang dikembangkan oleh Ganes, Arnold dan Reynold (2006) terdiri dari 24 butir pernyataan yang mencakup 3 dimensi yang dapat menimbulkan perilaku Brand Switching konsumen, yaitu keinginan untuk berpindah pada merek lain, ketidaksediaan menggunakan kembali merek yang sama, dan keinginan untuk mempercepat penghentian pemakaian (Ganesh dkk., 2006).

Berikutnya adalah skala mengukur tingkat kepuasan konsumen yang dikembangkan oleh Wilkie (1994). Ada 27 butir pernyataan yang mencakup 5 elemen yaitu harapan, kinerja, perbandingan, Confirmation, dan ketidaksesuaian (Wilkie, 1994). Selanjutnya adalah skala mengukur tingkat kepercayaan konsumen yang dikembangkan oleh Chauduri dan Holbrook (2001)(Ganesh dkk., 2006). 24 butir pernyataan mencakup empat indikator dalam mengukur kepercayaan konsumen terhadap merek yang meliputi kepercayaan, dapat diandalkan, jujur (Honest), dan keamanan (Ganesh dkk., 2006). Analisis data menggunakan Regresi Linier Berganda dengan bantuan program Statistical Product and Service Solution (SPSS).

\section{Hasil Penelitian}

Berdasarkan hasil analisis di atas diketahui bahwa nilai t sebesar 7.132 dengan $P$ $=000<0.05$ artinya secara simultan terdapat hubungan antara kepuasan dan kepercayaan konsumen terhadap Brand Switching pada kosmetik berlabel halal. Namun saat diuji secara parsial di dapatkan hasil yaitu nilai $P=0.489>0.05$ artinya tidak terdapat hubungan antara kepercayaan konsumen terhadap Brand Switching pada kosmetik berlabel halal. Dan terdapat hubungan antara kepuasan konsumen terhadap Brand Switching pada kosmetik berlabel halal di lihat nilai $P=.0 .012<0.05$.

\begin{tabular}{|c|c|c|c|c|c|c|}
\hline \multicolumn{7}{|c|}{$\begin{array}{c}\text { Tabel } 1 \\
\text { Koefisien }\end{array}$} \\
\hline & & \multicolumn{2}{|c|}{$\begin{array}{l}\text { Koefisien tidak } \\
\text { distandarisasi }\end{array}$} & \multirow{2}{*}{$\begin{array}{c}\text { Koefisien } \\
\text { distandarisasi }\end{array}$} & \multirow[b]{2}{*}{$\mathrm{t}$} & \multirow[b]{2}{*}{ Sig. } \\
\hline \multicolumn{2}{|l|}{ Model } & $\mathrm{B}$ & Std. Error & & & \\
\hline \multirow[t]{3}{*}{1} & (Konstan) & 105.498 & 14.793 & & 7.132 & .000 \\
\hline & $\begin{array}{l}\text { Kepercayaan } \\
\text { Konsumen }\end{array}$ & .120 & .172 & .102 & .695 & .489 \\
\hline & $\begin{array}{l}\text { Kepuasan } \\
\text { Konsumen }\end{array}$ & -.369 & .143 & -.380 & -2.583 & .012 \\
\hline
\end{tabular}


Adapun nilai R Square (koefisien determinasi) yang dihasilkan adalah 0.107 yang berarti bahwa 10.7\% perilaku Brand Switching konsumen di pengaruhi oleh kepuasan dan kepercayaan mereka terhadap produk atau merek tersebut, sedangkan $80.3 \%$ di pengaruhi oleh variabel lain.

Tabel 2

Model Summary

\begin{tabular}{llccrr}
\hline Model & R & R Square & Adjusted R Square & $\begin{array}{c}\text { Std. Error of the } \\
\text { Estimate }\end{array}$ & Durbin-Watson \\
\hline 1 & $.327^{a}$ & .107 & .080 & 11.44333 & 1.821 \\
\hline
\end{tabular}

\section{Pembahasan}

Berdasarkan hasil analisis regresi linier berganda yang dianalisa secara simultas didapatkan hasil yang menunjukkan terdapat hubungan antara kepuasan dan kepercayaan konsumen terhadap Brand Switching pada kosmetik berlabel halal. Namun hanya 10.7\% perilaku Brand Switching konsumen di pengaruhi oleh kepuasan dan kepercayaan mereka terhadap produk atau merek tersebut, sedangkan $80.3 \%$ di pengaruhi oleh variabel lain. Dengan kata lain sejumlah faktor seperti atribut produk dan promosi (Tjiptono, 1997), persediaan produk (Aaker, 1996), ketidakpuasan konsumen (Ribhan, dalam Rasyada \& Seotrizola, 2015), Variety Seeking, harga (Lamb dkk., 2001) dan iklan memungkinkan konsumen untuk tertarik berpindah pada merek lain.

Hasil tersebut sejalan dengan penelitian yang dilakukan oleh Raza yang menunjukkan bahwa terdapat 4 faktor yang memainkan peran penting dalam perilaku Brand Switching konsumen yaitu kualitas layanan, citra merek, kepercayaan, dan kepuasan (Raza, 2015). Kotler dan Amstrong juga menegaskan bahwa kepercayaan adalah sebuah pemikiran deskriptif yang dimiliki seseorang tentang sesuatu (Philip Kotler \& Amstrong, 2017). Dengan membentuk kepercayaan pada konsumen merupakan salah satu cara untuk menjadikan konsumen tersebut loyal pada suatu produk atau merek. Namun kepercayaan konsumen terhadap produk juga memiliki hubungan terhadap adanya perpindahan merek (Brand Switching), dimana kepercayaan konsumen berpengaruh pada sikap yang terdiri dari 3 komponen yakni kognitif kaitannya dengan proses pembelajaran konsumen, afektif memiliki keterkaitan dengan sikap itu sendiri, dan konatif kaitannya dengan perilaku. Jika tingkat kepercayaan konsumen rendah terhadap produk atau merek maka akan terbentuklah intention to Brand Switching (Assael, 1998).

Sikap sendiri berpengaruh pada perilaku yang secara umum bergantung pada keterlibatan konsumen dalam menggunakan suatu produk atau merek. Jika konsumen memiliki keterlibatan yang rendah pada pembelian suatu produk atau merek maka akan rendah pula hubungannya pada kepercayaan konsumen para produk atau merek tersebut dan akan lebih tinggi hubungannya terhadap beralihnya konsumen para produk lain (Brand Switching) (Setiadi, 2003). Sedangkan menurut Kotler dan Armstrong, Dick dan Basu kepuasan konsumen merupakan keadaan di mana konsumen merasa cocok atau puas dengan produk yang telah digunakan karena sesuai dengan harapan dari konsumen (Dick \& Basu, 1994; P. Kotler \& Amstrong, 2003). Konsumen akan merasa puas jika apa yang di harapkan dalam sebuah produk terpenuhi, namun hal ini tidak menutup kemungkinan terjadinya perpindahan merek, sebab konsumen merasa ingin mencari variasi baru atau ingin mencoba produk baru yang belum pernah ia gunakan, karena pencarian variasi adalah sebuah motif lazim yang dilakukan oleh konsumen. Biasanya konsumen yang memiliki keterlibatan emosional rendah serta kesadaran konsumen akan adanya perbedaan antara merek yang ia gunakan dengan merek lainnya rentan dalam melakukan perpindahan merek pada produk lain. Hal inilah yang menjadi perhatian para pelaku ekonomi akan keberhasilan produk yang ditawarkan di masyarakat (Assael, 1984). 
Selanjutnya terdapat hubungan antara kepuasan konsumen terhadap Brand Switching pada kosmetik berlabel halal. Meskipun para pegawai wanita di UIN Sunan Ampel Surabaya merasa puas dengan produk atau merek yang mereka gunakan, namun tetap membuat mereka melakukan perilaku Brand Switching. Salah satu penyebabnya adalah keinginan mencari variasi baru atau mencoba produk baru yang belum pernah ia gunakan. Biasanya konsumen yang memiliki keterlibatan emosional rendah serta kesadaran konsumen akan adanya perbedaan antara merek yang ia gunakan dengan merek lainnya rentan dalam melakukan perpindahan merek pada produk lain. Sehingga ini yang menjadi perhatian para pelaku ekonomi akan keberhasilan produk yang ditawarkan di masyarakat (Assael, 1984). Hal ini juga di dukungoleh hasil deskripsi produk kosmetik yang digunakan oleh para pegawai wanita UIN Sunan Ampel Surabaya, di mana sekitar $71,4 \%$ tidak hanya menggunakan satu produk kosmetik melainkan banyak produk yang digunakan dalam satu waktu.

Hasil penelitian ini sejalan dengan penelitian yang dilakukan oleh Siska yang menunjukkan bahwa atribut produk, dan kepuasan berpengaruh terhadap Brand Switching konsumen (Siska, 2010). Serta di dukung oleh penelitian yang dilakukan oleh Ayu Ningsih yang menunjukkan bahwa kepuasan, secara parsial berpengaruh terhadap terhadap Brand Switching produk pembersih wajah biore menuju pembersih wajah merek pond's (Ningsih, 2012). Namun hasil penelitian ini tidak sejalan dengan penelitian yang dilakukan oleh Teguh yang dalam penelitiannya mendapatkan hasil yang menunjukkan bahwa ketidakpuasan konsumen, kebutuhan untuk mencarian variasi dan karakteristik kategori produk berpengaruh terhadap perilaku Brand Switching konsumen (Teguh, 2013).

Sedangkan pada uji selanjutnya menunjukkan hasil menyatakan bahwa tidak terdapat hubungan antara kepercayaan konsumen terhadap Brand Switching pada kosmetik berlabel halal, dan dari hasil perbandingan antara nilai rata-rata menunjukkan bahwa kepercayaan para pegawai UIN Sunan Ampel Surabaya terhadap merek kosmetik juga tinggi. Sehingga hal ini sesuai dengan teori yang dikemukakan oleh Kotler \& Amstrong yang menyatakan bahwa kepercayaan konsumen merupakan sebuah pemikiran secara deskriptif yang dimiliki seseorang tentang sesuatu (Philip Kotler \& Amstrong, 2017). Dengan membentuk kepercayaan pada konsumen merupakan salah satu cara untuk menjadikan konsumen tersebut loyal pada suatu produk atau merek. Sehingga saat konsumen sudah percaya dengan suatu merek atau produk maka tingkat loyalitas konsumen akan tinggi pada merek atau produk tersebut.

Hasil penelitian ini di dukung oleh penelitian yang dilakukan oleh Karina yang menunjukkan bahwa citra merek, kepercayaan, dan produk halal secara bersamaan dan parsial memiliki nilai positif dan dampak signifikan pada kesetiaan (Karina, 2018). Namun tidak sejalan dengan hasil penelitian yang di lakukan oleh Setiawan yang menunjukkan bahwa atribut produk, kepercayaan dan ketidakpuasan konsumen berpengaruh terhadap respon emosi. Respon emosi dapat berpengaruh pada kepercayaan dan ketidakpuasan konsumen yang berdampak terhadap keputusan konsumen untuk berpindah. Sehingga apabila respon emosi konsumen meningkat maka keputusan perpindahan konsumen akan meningkat (Setiawan, 2013).

\section{Simpulan dan Saran}

Kepuasan dan kepercayaan konsumen dapat membentuk perilaku Brand Switching pada pengguna kosmetik berlabel halal. Kontribusi dari kedua variabel tersebut memang sangat kecil sehingga dapat dikatakan bahwa ada variable lain yang juga membentuk perilaku brand switching tersebut. Secara parsial kepercayaan konsumen tidak berhubungan dengan perilaku brand switching karena kepercayaan itu mendarat pada tiga komponen yaitu kognitif, afektif, dan konatif. Sementara kepuasan berhubungan dengan 
perilaku brand switching karena adanya keinginan untuk mencari atau mencoba produk baru yang belum pernah digunakan.

\section{Daftar Pustaka}

Aaker, D. A. (1996). Building Strong Brands. New York: : Penerbit Division of Simon \& Schuster Inc.

Assael, H. (1984). Consumer Behaviour and Marketing Action (8th ed.). Massachusetts: Kent PublishingCompany.

Assael, H. (1998). Consumer Behavior and Marketing Action. New York: International Thomson Publising.

Bahtiyar, A. (2013). Analisis Pengaruh Iklan Pesaing, Ketidakpuasan Pelanggan, dan Kebutuhan Mencari Variasi terhadap Perpindahan Merek Pasta Gigi Formula di Wilayah Perkotaan Kabupaten Jember. Jurnal Universitas Jember.

Chan, A. (2010). Pengaruh Ekuitas Merek Terhadap ProsesKeputusan Pembelian Konsumen. Jurnal Administrasi Niaga Fakultas Ilmu Sosial dan Ilmu Politik UniversitasPadjadjaran.

Chatrin, K., Sherly. (2006). Analisis Faktor-Faktor yang Mempengaruhi Brand Switching Terhadap Bread Boutiques di Supermall Pakuwon Indah (SPI) Surabaya. Jurnal Universitas Kristen Petra. Surabaya.

Dick, A. S., \& Basu. (1994). Customer Loyalty: Toward an IntegratedConceptual Framework. Journal of the Academy of Marketing Science, 22(2), 99-113.

Ganesh, J., Arnold, M. J., \& Reynolds, K. E. (2006). Understanding theCustomer Base of Service Providers: An Examination of theDifferences between Stayers and Switchers. Journal of Marketing, 64(3), 65-87.

Giese, J. L., \& Cote, J. A. (2002). Defining Consumer Satisfaction. Academy of Marketing Science Review, 2000(1). Diambil dari http://www.amsreview.org/articles/giese01-2000.pdf

Gunawan, F. (2010). Pengaruh Persepsi Merek dan Kepercayaan Konsumen atas Produk terhadap Brand Switching atas Produk Smartphone (Blackberry) pada Mahasiswa UNP. Jurnal Fakultas Ekonomi Universitas Negeri Padang.

Hidayat, A. S., \& Siradj, M. (2015). Sertifikasi Halal dan Sertifikasi Non Halal Pada Produk Pangan Industri. Jurnal Asosiasi Pengacara Syariah Indonesia (DPN APSI), XV(2).

Hidayat, E. (2018). The Business Actors' Response to The Liability of Determining Halal Certification for Ayam Penyet Surabaya and Super Geprek Sleman Yogyakarta. Jurnal Universitas Islam Indonesia.

Hutami, R. A. (2018). Pengaruh Pola Belanja, Harga, dan Kualitas Pelayanan terhadap Impulse Buying di Toko Jolie Wirobrajan [Skripsi]. Universitas Mercu Buana Yogyakarta.

Karina, K. (2018). Effect and Impact of Brand, Trust, and Halal Productsntowards Switching Barrier on the Loyality of Tabita Cosmetik Users (Case Study: Students of Faculty of Economucs and Business, UNPAB). Saudi Journal of Humanities and Social Sciences (SJHSS). Scholars Middle East Publishers.

Khairani, N. (2011). Analisis Pengaruh Citra Merek, Ketidakpuasan Konsumen, Iklan, Word of Mouth, dan Karakteristik Kategori Produk terhadap Keputusan Perpindahan Merek pada Sabun Pembersih Wajah [Skripsi]. Fakultas Ekonomi Universitas Diponegoro Semarang.

Kotler, P. (2008). Manajemen Pemasaran. Jakarta: Indeks.

Kotler, P., \& Amstrong. (2003). Dasar-dasar Pemasaran, Jilid 1 (Sembilan). Jakarta: PT. Indeks Gramedia.

Kotler, Philip, \& Keller, K. L. (2010). Marketing 14. Prentice Hall. Pearson. 
Kotler, Philip, \& Amstrong, G. (2017). Prinsip-Prinsip Pemasaran (13 ed., Vol. 1). Jakarta: Erlangga.

Lamb, C. W., Hair, J. F., \& McDaniel, C. (2001). Marketing (1 ed.). Jakarta: Salemba Empat.

Lau, G. T., \& Lee, S. H. (1999). Consumers' Trust in a Brand and the Link to Brand Loyalty. Journal of Market Focused Management, 4, 341-370.

Muhid, A. (2019). Analisis Statistik: 5 Langkah Praktis Analisis Statistik dengan SPSS for Windows (2 ed.). Sidoarjo: Zilfatama Jawara.

Mutaalimah, S. (2018). Pengaruh Harga, Kualitas Produk dan Religiusitas terhadap Perilaku Pembelian Produk Kecantikan Sariayu Berlabel Halal. Jurnal Universitas Islam Indonesia.

Ningsih, A. (2012). Pengaruh Kepuasan Konsumen, Brand Awareness dan Sikap Konsumen terhadap Brand Switching Produk Pembersih Wajah Biore menuju Pembersih Wajah Merek Pond's. Jurnal Program Studi Pendidikan Ekonomi Sekolah TinggiKeguruan dan Ilmu Pendiddikan (STKIP PGRI) Sumatera Barat Padang.

Rasyada, \& Seotrizola. (2015). Pengaruh Iklan dan Perilaku Mencari Variasi terhadap Brand Switching Kartu Seluler pada Mahasiswa Fakultas Ekonomi Universitas Negeri Padang. Jurnal Praktik Bisnis, 4(1).

Raza. (2015). Factors Affecting Brand Switching in Telecommunication Sector. Journal of Research in Business and Management, 3(1), 11-15.

Setiadi, N. (2003). Perilaku Konsumen: Konsep dan Implikasi untuk Strategi dan Penelitian Pemasaran. Bogor: Kencana.

Setiawan, E. A. (2013). Analisis Atribut Produk, Ketidakpuasan Konsumen dan Kepercayaan terhadap Keputusan Perpindahan Melalui Respon Emosi sebagai Variabel Intervening. Jurnal STIE Widya Manggala Semarang.

Shukla. (2004). Princip lesof Soil Physics. New York: Marcel Dekker, Inc.

Siska. (2010). Pengaruh Atribut Produk, Kepuasan dan Variety Seeking terhadap Brand Switching Konsumen Rinso ke Merek lain di Kota Padang. Jurnal Ekonomi Fakultas Ekonomi Universitas Negeri Padang.

Tauriana, \& Christine. (2011). Analisis Hubungan Service Recovery terhadap Complaining Behavior dan Dampaknya terhadap Brand Switching. Jurnal Fakultas Ekonomi dan Bisnis Bina Nusantara University. Binus Business Review, 2(1), 115-123.

Teguh. (2013). Pengaruh Ketidakpuasan Konsumen dan Karakteristik Kategori Produk terhadap Keputusan Perpindahan Merek dengna Kebutuhan Mencari Variasi sebagai Variabel Moderasi. Jurnal Buletin Studi Ekonomi, 18(2).

Tjiptono, F. (1997). Strategi Pemasaran (1 ed.). Yogyakarta: Andi.

Tripeni, P. (2018, Maret 30). Mengenal ketentuan kosmetik berlabel halal dari LPPOM MUI. Diambil 5 Oktober 2018, dari http://m.cnnindonesia.com/gaya-hidup /2018329232035-277-287005/mengenal-ketentuan-kosmetik-berlabel-halaldari-lppom-mui.

Widyasari, S. (2008). Analisis Perilaku Brand Switching Konsumen dalam Pembelian Produk Sepeda Motor (Studi Pada Konsumen Sepeda Motor di Kotamadya Salatiga). Jurnal Bisnis dan Ekonomi (JBE), 15(2), 107-127.

Wilkie, W. L. (1994). Consumer Behavior (3 ed.). New York: Jhon Wiley \& Sons Inc.

Yoestini. (2012). Analisis Pengaruh Harga, Kualitas Produk, dan Kualitas Layanan terhadap Kepuasan Pelanggan. Jurnal Fakultas Ekonomika dan Bisnis Universitas Diponegoro. 